This item was submitted to Loughborough's Research Repository by the author.

Items in Figshare are protected by copyright, with all rights reserved, unless otherwise indicated.

\title{
Who gains from restructuring the post-Soviet transition economies, and why?
}

PLEASE CITE THE PUBLISHED VERSION

LICENCE

CC BY-NC-ND 4.0

\section{REPOSITORY RECORD}

Edwards, T. Huw. 2019. "Who Gains from Restructuring the Post-soviet Transition Economies, and Why?". figshare. https://hdl.handle.net/2134/337. 


\title{
Who Gains From Restructuring the Post-Soviet Transition Economies, and Why?*
}

\author{
T.Huw Edwards \\ Centre for the Study of Globalisation and Regionalisation \\ Warwick UK \\ Tel (44)024-7652-4462 \\ Fax 024-7657-2548 \\ T.H.Edwards@warwick.ac.uk
}

June 2004

\begin{abstract}
$\{$ Post-Soviet restructuring has produced mixed economic results. In general, the more advanced countries, which have now joined the European Union, have fared better, while those further East in the CIS have seen a combination of rapid falls in measured gross domestic product and wages, followed by prolonged recession, while the large gains to a wealthy minority who gained from privatisations have largely been reinvested abroad, following capital flight. I set up a series of theoretical and numerical simulation models, based upon a batting order approach where reform means closure of inefficient capacity. In the presence of significant costs to new firm entry and international capital mobility, restructuring and privatisation can lead to falls in GDP and real wages, while capital is transferred abroad. This situation can occur even under perfect competition, but is worse when industrial production is concentrated and trade costs are high. By contrast, workers can gain when costs of establishing new firms are low, and/or when the inefficient industries are capital-intensive. For countries with high costs of firm setup and of trade, capital controls may be justified to protect wages.
\end{abstract}

KEYWORDS: Transition, wages, general equilibrium

JEL Classification: P30, D58, D33

${ }^{*}$ The author thanks David Barlow at University of Newcastle for invaluable comments and suggestions. Any errors are my own. 


\section{Introduction}

Post-Soviet restructuring has produced mixed economic results. In general, the more advanced countries, which have now joined the European Union, have fared better, while those further East in the CIS have seen a combination of rapid falls in measured gross domestic product and wages, followed by prolonged recession, while the large gains to a wealthy minority who gained from privatisations have largely been reinvested abroad, following capital flight. In this paper I set up a series of theoretical and numerical simulation models to help explain this phenomenon. I first examine traditional neoclassical and macroeconomic models of restructuring, but then argue they are inappropriate for understanding a post-communist transition. As an alternative, I develop an approach based upon a batting order model where reform means closure of inefficient capacity. In the presence of significant costs to new firm entry and international capital mobility, restructuring and privatisation can lead to falls in GDP and real wages, while capital is transferred abroad. This situation can occur even under perfect competition, but is worse when industrial production is concentrated and trade costs are high. By contrast, workers can gain when costs of establishing new firms are low, and/or when the inefficient industries are capital-intensive. For countries with high costs of firm setup and of trade, capital controls may be justified to protect wages.

\section{The Restructuring Experience of the Post-Soviet Economies}

The experiences of the post-Soviet economies can broadly be split into four groups. Barring perhaps the Baltic states, none has to date seen a miracle comparable to that experienced in China following its reforms, though this may reflect a number of factors. The most encouraging experiences have been those of the Central and East European accession states to the EU, whose economies were already somewhat more open and had larger private sector involvement before transition, and which generally had less deep transitional recessions than the other former Soviet bloc economies (though still very marked). Output had generally recovered to pre-transition levels by the end of the 1990s, helped by inward foreign direct investment flows, 
and consumer living standards had risen. ${ }^{1}$ These economies have seen a moderate increase in income inequalities, from a starting point which was somewhat more equal than Western Europe. ${ }^{2}$

The second group, the South East European states of the Balkans, had a more marked transitional recession and took longer to recover, as well as seeing worsened income inequality. ${ }^{3}$. The third group is essentially Russia, which undertook partial economic reforms, and saw a slump in incomes, hugely increasing inequality, ${ }^{4}$ and capital flight (Gros and Steinherr estimate $\$ 134 \mathrm{bn}$ cumulative capital flight by 2001, using IMF data). The fourth group, which includes many of the remaining CIS economies, has seen little reform to date, and has seen a huge general income slump, even more marked than Russia, though the increase in measured inequalities has been less marked than in Russia.

One feature of the restructuring has been a fall everywhere in the share of income accruing to labour. This reflects partly a redistribution towards capital necessary to restore normal profits, but also a growth of monopolistic (supranormal) profits, as well as a rising share of unemployment and other benefits in total income. The fall in labour's share has been more marked in the more Eastern economies, which had also seen a greater fall in total incomes during transition and less inflow of FDI.

\footnotetext{
${ }^{1}$ See Gros and Steinherr, 2004, for a good overall summary

${ }^{2}$ The Gini coefficient rose by 7 per cent in Poland and 2.6 per cent In Slovenia 1989-95, and by 2.2 per cent in Hungary 1989-93 (Milanovic, 1999)

${ }^{3}$ Bulgaria's Gini coefficient rose by 10 percentage points.

${ }^{4}$ Russia's Gini coefficient rose by 23 percentage points 1989-94, taking it near to Latin American levels of inequality.
} 
Table 1:Wages share in disposable income before transition compared to 1993-6

(source Milanovic, 1999)

$\begin{array}{lll}\text { Country } & \text { Pre-Transition } & \text { Transition } \\ \text { Bulgaria } & 57 & 47 \\ \text { Hungary } & 60 & 50 \\ \text { Poland } & 55 & 44 \\ \text { Slovenia } & 67 & 57 \\ \text { EASTERN EUROPE } & 60 & 50 \\ \text { Russia } & 74 & 55 \\ \text { Latvia } & 82 & 50 \\ \text { FSU } & 78 & 53\end{array}$

While changes in inequality are by no means only a question of the distribution of income between wages, profits and transfers, the issue of why wage-earners - and particularly low wage-earners - seem to have particularly borne the burden of reform is an important one, and raises questions such as which of the transitional reforms have hurt wage-earners, and which have helped them. It is also important because, as Alesina and Rodrik (1994) have pointed out, large increases in inequality, and particularly a fall in the incomes of median wage-earners, can create a political block on further economic reforms and hinder the long-term growth of economies.

There is, of course, a second aspect of 'big bang' restructuring which may also affect post-transition income redistribution: namely the allocation method of shares in privatised enterprises. A variety of methods have been tried or suggested, varying from voucher privatisations through management buyouts to shares-for-debt swaps with banks and direct sell-offs to foreign firms, to the direct auctioning of firms or simply giving away shares to the public (see Gros and Steinherr, 2004). While these vary in their distributional effects, it is probably fair to say that most of the privatisations in practice have resulted in a minority creaming off the main capital gains. ${ }^{5}$ In this paper, I take it for granted that little of the potential

\footnotetext{
${ }^{5}$ In this regard, the shares-for-debt swaps with the banks run by emerging oligarchs in Yeltsin's Russia seem to have had the worst distributional effects.
} 
market value of firms privatised accrues to the typical wage-earner.

\section{Traditional Approaches to Restructuring.}

\subsection{Neoclassical models}

I first consider approaches to analysing the restructuring experience based upon a perfectly competitive, neoclassical model. In particular, two interpretations are given: first, that the restructuring involves the reduction of an excessive initial capital stock (reflecting the high levels of fixed capital formation encouraged by the Soviets as a matter of economic policy) and secondly, examining the effects of removing sectoral misallocations and cross-subsidies.

\subsection{A one-sector model: overcapitalisation}

A one-sector neoclassical approach to restructuring assumes that technology and underlying efficiency of production are exogenously given, and that output $Y$ is produced as a function of two input factors $K$ and $L$ under constant returns to scale but diminishing returns to substitution:

$$
Y=Y(K, L)
$$

where $d Y / d K<0$. The price of labour is the wage rate $w$, while the cost of capital is the price of capital inputs (normalised as the price of output, equal to 1) multiplied by interest plus depreciation. Since the Soviet economic system was geared to producing high rates of forced investment, at the cost of consumer goods in the short run, this might well be interpreted in a neoclassical model as over-supply of capital (effectively a subsidised interest rate $r$ at below the world interest rate $r^{\prime}$ ). To the extent that monetary prices are realistic at all, the industrial sector therefore makes a loss, due to excess capital investment.

The impact of big bang market reforms in a neoclassical economy with excess capacity would be a sharp rise in the real interest rates facing businesses, and a closing of excess capacity. Since $K$ is reduced while $L$ is constant, total output $Y$ is also reduced: this would be measured as a fall in real GDP. Given the size of the rationalisation which occurred in the early years of transition, this model is quite consistent 
with considerable falls in GDP. Wages would also fall substantially in real terms, since, with less capital employed, the marginal product of labour is reduced. Furthermore, this fall in GDP and wages would be a long-run phenomenon.

However, interpretation of this GDP and wage fall would need to be interpreted with extreme care. The excess investment means that some of the pre-reform capacity was not producing enough returns at the margin to cover its interest and depreciation costs. Reducing that capacity means that depreciation costs to the economy are greatly reduced: consequently Net Domestic Product might well rise, even if GDP has fallen. Moreover, if we assume putty capital, the economy can immediately export capital to other countries where the return is greater, so yielding interest, profit and dividend flows from abroad (hence raising Net National Product). In a more realistic model, scrapping excess capacity means writing off capital rather than shifting it abroad, but in the long run investment would be directed more abroad, so yielding net interest and profit inflows.

The fall in real wages is also misleading, since there would presumably be a reduction in the taxation (or taxation-equivalent goods rationing) needed to pay for the subsidies to investment. Take-home wages would rise. Effectively, the above neoclassical model assumes that, under the Soviet system, current consumption has been excessively sacrificed for the sake of future consumption: the post-Soviet restructuring would be in the form of a fall in investment to allow increased consumption today.

The obvious problem with the simple neoclassical interpretation is that, while Stalinist rates of forced investment (as a percentage of GDP) may indeed have been excessive compared to the West, it is hard to argue that the Soviet economy was really suffering from excessive capital stock and over-production, given that its capital stock and GDP per head fell well short of Western levels. While overcapitalisation before the Soviet breakup might indeed explain the capital flight from Russia which has taken place since, it is less consistent with the experience of the Central and Eastern European Countries (CEECs), which have been large-scale capital importers. 


\subsection{A two-sector approach: misallocation}

A more sophisticated neoclassical-based approach would be to attempt to interpret inefficiency in the Soviet era economies in terms of a sectoral misallocation, reflecting the protection of some industrial sectors, the diversion of trade away from the West to inter-Soviet or inter-CMEA trade and the effects of high government spending on certain areas (particularly the military). In a multi-sector neoclassical model these effects would be captured by removing a set of tariffs, quotas and tariff-equivalent distortions from certain industries, so leading to a reallocation of production in a way which more accurately reflects underlying comparative advantage. This should lead to a rise in production and incomes (unless tariffs are reduced below optimal levels). However, it is worth remembering that individual countries or regions may have gained from trade diversion under the Soviet/CMEA system, and so might have lost from the Soviet breakup and liberalisation of trade (while others, which were effectively subsidising them, would have gained).

Removal of sectoral distortions might indeed result in significant increases in output per head: the most notable case of this is energy prices, which were maintained at below-World levels throughout the later Soviet period, and continued at subsidised levels within the Russian economy even after the Soviet breakup. Gros and Jones (1991) estimated a welfare loss from energy subsidies of at least 10 per cent of Soviet GDP, though there might, of course, be short-run costs to any reforms. It is also worth noting that, in the long run, removing sectoral distortions should raise the marginal product of capital schedule, and so lead to higher levels of capital per head.

\subsection{Macroeconomic models}

The above models largely assume costless factor mobility. By contrast, the other main school of restructuring models, the macroeconomic restructuring models (see e.g. Blanchard, 1997, Castanheira and Roland, 2001) assume mobility costs and high transitional unemployment. In the simplest model of this sort (Blanchard), a subsidised sector is forced to contract rapidly by reforms. A higher-productivity sector grows to replace it, but there are constraints on the rate at which this can grow (organisational problems, shortages of the right types of capital, factor mobility costs etc). Consequently there is a marked transitional 
recession, where factors laid off from one sector do not find immediate re-employment: this will of course have Keynesian multiplier effects across the whole economy. In this type of model, there are substantial short-run costs to the restructuring, though in the long run wages and GDP should rise.

However, while all the above models have some validity, they also all have problems. While the macroeconomic models correctly imply a sharp transitional recession, unemployment has rarely risen to a degree commensurate with the amount of capacity closure. ${ }^{6}$ Moreover, many of the transition economies have failed to show the kind of recovery that a short-term restructuring recession model would indicate.

As for traditional neoclassical general equilibrium analysis: the focus on taxes, tariffs and subsidies and upon the associated sectoral and geographical misallocations of resources gives only a very limited view of the degree and type of economic inefficiencies resulting from a Soviet-style central planning system. In the first place, sectoral misallocation was rarely driven by explicit subsidy. In the former Soviet Union in particular, allocation was determined by central planning, and firms were able to sell their output in part because rival sources (eg imports) were only available in limited, rationed quantities, and because people had more money available than there were price-rationed goods on which to spend it.

But even when the effects of these sectoral and geographical misallocations are converted into tariff- or subsidy-equivalents (and arguably Hungary and Czechoslovakia at least did have fewer overall shortages and more market-clearing prices) the effects of Soviet-style distortions are grossly underestimated just by treating them as if they were Western-style subsidies.

Subsidies and other forms of protection under the Soviet system had numerous detrimental aspects. Sectoral misallocation and 'overcapitalisation' hav already been mentioned. However, arguably just as important was the interference with the process of search for efficient allocation and production/management techniques to which, in a Western economy, the closure and restructuring of plant contributes. At a more micro-level, soft budget constraints disincentivised local management: effectively firms had a blank cheque, as long as they met adequately their centrally-allocated production targets. This meant that they had little incentive to improve efficiency. While the central planners could in theory have acted to close or reorganise

\footnotetext{
${ }^{6}$ Though there have been reductions in labour force participation in some post-Soviet economies.
} 
inefficient enterprises, this was a rare occurrence, reflecting a lack of incentives on the planners' part and a shortage of information, as well as political factors.

\section{A Simple Batting-Order Approach}

In this paper I explore a modified version of the neoclassical formulation above. The algebraic formulation is set out in detail in Appendix 2 - the description here is nontechnical. As in the traditional neoclassical model, labour is perfectly mobile between uses (though, unlike the simpler neoclassical models, capital is not). However, it is not assumed that all investment is equally effective - in either a capitalist market or a socialist planned economy. Rather, it is assumed that each unit of capital invested is to set up one plant/firm/enterprise (the terms are used interchangeably in this simple model). This produces a firm level of output $Y_{f}$ depending upon the firm's individual efficiency, $\phi_{f}$, and upon labour input $L_{f}$

$$
Y_{f}=Y\left(\phi_{f}, L_{f}\right)
$$

I make the usual assumptions $d Y_{f} / d L_{f}>0, d_{2} Y_{f} / d L_{f}^{2}<0 . \phi_{f}$ is random, and not known in advance of the initial firm investment. Consequently, some firms will make supernormal profits, while others will make inadequate operating profit to cover interest costs and depreciation.

The key difference between a Soviet-style planned economy and a Western market economy is assumed to be the way in which inefficient firms are handled. It is assumed that the system of soft budget constraints ensured, that, under the Soviet system, inefficient firms remained open and were able to find enough subsidy to cover depreciation and interest costs (if any interest were ever charged). This would tally with the planners maximising short-run output. Meanwhile, all industrial profits would be reinvested, so that, as returns to capital in the economy as a whole dwindled, eventually a stagnant equilibrium would be reached where profits of the successful firms were entirely used up in cross-subsidising the bad firms.

For simplicity I assume, perhaps unrealistically, that firms were efficient in their labour hiring decisions, so that successful enterprises hired more labour and produced far more output than unsuccessful ones. Again unrealistically (given the highly concentrated market structures of some of the transition economies) 
I assume initially all enterprises/firms are price takers, and that prices are set exogenously on world markets and normalised at 1 . This assumption is relaxed in a later section.

Following the market reform of the economy, subsidies to the unsuccessful firms are cut off, and those which cannot make a profit are forced to close. The remaining firms stay open and expand output and employment. I ignore labour market frictions in this simple model, and so assume full employment.

Figure 1 (Appendix 1) shows what happens to employment following the transition reforms, in the case where no new firms are set up. On the $X$ axis, firms are ranked according to their underlying efficiency, $\phi_{f}$, which I assume, for simplicity, is uniformly distributed between 0 and unity. Figure 1 shows employment by each firm before and after the transitional reforms: employment is assumed to rise with firm efficiency (which would be the case if labour hiring were rational). Prior to the transitional reforms, the firms to the right of $\phi^{*}$ were profitable, and cross-subsidised those to the left of it. After the reforms, firms with $\phi_{f}>\phi_{1}$ will break even, while firms to the left of that point shut. With an efficient labour market, the remaining firms expand employment (so that total employment remains constant, equal to the inelastic total supply of labour). To achieve this, real wages must fall. One consequence of this is that $\phi_{1}<\phi^{*}$, hence some firms which were marginally unprofitable prior to the reforms will stay open. The dashed line shows the higher employment levels for the remaining firms post-reform.

Output by the remaining firms will also rise after reform, as their labour force increases, but it is not difficult to show this is by less than the fall in gross output by the enterprises which have been shut. Hence there will be a decline in measured GDP. However, as the closed enterprises had not been producing enough to cover their interest and depreciation costs, Net Domestic Product will fare much better than GDP (lower depreciation) and, at least in the long run, if the savings on capital maintenance and replacement costs are reinvested abroad Net National Product (and total consumer spending) will rise.

However, while this model, in common with the one-sector neoclassical model, indicates that the expected GDP fall in transition does not imply falling real consumption, it does suggest serious distributional implications: particularly if privatisations carried out during the transitional process fail to raise the full market value of the firms as revenue, and/or if this revenue is not recycled efficiently to wage-holders. Essentially a sizeable potential redistribution in income is taking place from wage-earners to the new capital 
owners, and this clearly has long-run politico-economic significance.

A key element in considering the effects of a reform package is the nature of depreciation. In this paper I consider two possible types of depreciation. In the first type, there is a constant probability $\delta$ every year that all of a firm's capital will need replacing. The second type is where there is no replacement as such, but a constant ongoing maintenance cost of d per unit of initial capital expenditure every year. These are essentially two polar cases.

If we assume first that proportion of all firms have to replace their complete capital stock every year, then those firms will have to choose whether to do so or not: all which have an annual operating profit less than $(r+\delta)$ will close when the time for capital renewal arrives. In this case, there will be a steady string of bankruptcies over several years, as the old loss-making firms are slowly closed. Eventually all firms whose quality falls below a new threshold, $\phi_{f}=\phi "$, will close. $\phi "$ will correspond to the situation where operating profits equal the user price of capital.

This gives the threshold below which firms will go bankrupt. The proportion of firms going bankrupt in the new equilibrium will equal $\phi "$. This will of course have to be solved as a simultaneous equation in $\phi "$ and real wage rate $w$ to clear the labour market. If there are no new firm startups, then the new equilibrium will therefore have a smaller number of enterprises (by factor $\phi^{\prime \prime}$ ) and a smaller capital stock and demand for replacement investment, but a larger amount of employment for all remaining firms to clear the labour market, which requires a lower real wage.

The alternative model of depreciation is that each firm has to make an upkeep expenditure of $\delta$ each year in order to stay in business. In this case, only a smaller proportion of capital costs ( $\delta$ as opposed to $r+\delta)$ is avoidable, and a smaller proportion of firms will shut, though they will shut faster. The fall in GDP and wages will be faster, but less in the long run than under the first depreciation model.

For the long-run effects of a big bang reform under these two depreciation scenarios, a numerical simulation is carried out.

\subsection{Numerical Analysis of a single-sector model.}

The model is initially calibrated to a starting case which approximately resembles Poland in 1989: 
Table 2: Initial data set for Poland 1989

Population m

GDP per Capita $\$ 000$

GDP \$bn

Labour share in GDP

Investment share in GDP

Initial assumed technical parameters

$\mathrm{w}=$ wage rate

$\mathrm{r}=$ interest rate per annum

$\delta=$ depreciation per annum
37.9

1.86

70.494

$50 \%$

$30 \%$

1

$5 \%$

$7.5 \%$

The elasticity of output with respect to labour can be shown (see Appendix 2) to equal the share of labour in GDP: ie $\alpha=1 / 2$. The initial capital stock (= no of firms) is 281.98, and the scale parameter $A$ initially equals 1 . The initial share of labour in net domestic product is 69.18 per cent. 
Table 3: Results of a simulated big bang reform, with no new firm entry.

Constant prob of replacement Ongoing annual maint cost

$\begin{array}{lcc}\text { Initial GDP } & 70.4 & 70.4 \\ \text { Final GDP } & 65.2 & 66.7 \\ \text { GDP Index (pre-transition=100) } & 92.6 & 94.7 \\ \text { Wage Index } & 92.6 & 94.7 \\ \text { Prop of firms shutting } & 43 \% & 35 \% \\ \text { Initial NDP } & 50.9 & 50.9 \\ \text { Final NDP } & 50.5 & 51.0 \\ \text { NDP index } & 99.2 & 100.3 \\ \text { long run NNP index } & 54.3 & 54.1\end{array}$

\section{More sophisticated batting order models.}

\subsection{Overcapitalisation}

It is first worth considering what the effects may have been of underpricing capital in the above model prior to transition. In particular, I will assume that, under the Soviet system, the State would overall charge zero interest to enterprises. Forced savings would raise the capital stock up to the point where industrial profits were exactly offset by depreciation on the existing capital stock. This would imply a far larger initial capital stock than in the previous model version. Its rundown would lead to a much greater fall in GDP and wages. However, the saving in wasted replacement investment expenditure would lead to large gains for the inheritors of industry post-privatisation, and in the long run reinvestment of capital (in the overseas markets) would lead to a large increase in net national product (which includes interest, profits and dividends from abroad) - though these gains would not accrue to wage-earners.

Table 4: Results of a simulated big bang reform, with no new firm entry. Assumed interest rate pre-transition $=0$. 


\section{Constant prob of replacement Ongoing annual maint cost}

$\begin{array}{lll}\text { Initial GDP } & 70.4 & 70.4 \\ \text { Final GDP } & 50.7 & 51.9 \\ \text { GDP Index } & 71.9 & 73.7 \\ \text { Wage Index } & 71.9 & 73.7 \\ \text { Prop of firms shutting } & 45 \% & 37 \% \\ \text { Initial NDP } & 31.9 & 31.9 \\ \text { Final NDP } & 32.5 & 32.2 \\ \text { NDP index } & 102.1 & 101.2 \\ \text { long run NNP index } & 152.5 & 147.8\end{array}$

The subsequent sections assume that there was no initial overcapitalisation, simply misapplication of capital.

\subsection{New Firm Startups.}

The conclusion that a restructuring reform will worsen wages, even in the longer run, may be altered if new firms are prepared to enter the market in large numbers.

If we assume that every firm has a startup cost $S$, and that new firms, like existing ones, vary in efficiency, but new firm $g$ does not know before they open what its efficiency level $\phi_{g}$ will be, then it follows that for each level of startup costs, $S$, there will be a corresponding wage $w^{* *}$ at which new firms will be indifferent between entering or not entering the market. At wages below $w^{* *}$ large numbers of new firms will enter, while above $w^{* *}$ none will enter.

It follows that, in a one-industry economy with all new firms facing startup costs $S$, there are two main types of long-run equilibrium: a) an equilibrium with no new firms setting up, and wages settling at the equilibrium level given by the model in the previous section (ie below the initial wage level $w_{0}=1$ ), but not low enough for new firms to enter. b) By contrast, if $S$ is small, new firms will enter until labour demand rises to set $w=w^{* *}$. 
If a new firm faces the same a priori efficiency distribution as existing firms, ${ }^{7}$ then if a new firm did not face startup costs it would expect to break even at the same wage as that at which existing firms break even (normalised at $w=1$ in our model). If our assumption about the pre-transition economy, where the industrial sector as a whole breaks even, then this would equal the pre-transition wage level. However, compared to the Soviet era when firms were never shut, new firms have an advantage: if firm $g$ enters the market and finds that its efficiency, $\phi_{g}$, is low, then it can choose to close (having just lost its setup cost plus the initial capital investment), whereas if $\phi_{g}$ is high it can continue producing. The net result is that, in a market economy, there is in the long run a premium in efficiency, productivity and profitability over just random efficiency, due to the market mechanism and the closure of unprofitable firms. So long as setup cost $S$ is not high enough to offset that premium, new firms will find it profitable to enter at the pre-Soviet wage, and wages may well be bid up rather than down as new firms enter the market.

The relationship between firm setup cost, $S$, and the long-term market clearing wage, based on the aggregate Polish data above is shown in Figure 2 (appendix).

As can be seen, when new firms can be set up costlessly, the long-run Darwinian effect of efficient new firms entering and surviving (while inefficient ones enter and close) means that wages are bid up higher than in the pre-transition economy, by nearly 15 per cent. This would also imply considerably higher GDP, and higher capital per head. By contrast, as the assumed firm setup cost rises, wages fall almost linearly, until at a setup cost $S$ of around 1 the wage falls to about the level at which it would be in a post-transition economy with no new firms (i.e. around $94 \%$ of pre-transition levels). At higher levels of $S$ than this, no new firms will enter.

\subsection{Multi-Sectoral Effects.}

In practice, economies consist of a variety of sectors, and part of the result of economic autarky (to say nothing of the other quirks of the Soviet planning system) was to protect certain sectors relative to others. Post-Soviet economies have undergone large structural changes, with the rapid decline of heavy industry

\footnotetext{
${ }^{7}$ I assume both $\phi_{f}$ and $\phi_{g}$ are distributed uniformly between zero and unity.
} 
and growth of services. For example, the table below shows changes in the structure of GDP in Poland over the period 1987-1993, indicating the large degree of rapid restructuring which took place:

Table 5: Poland 1987 and 1993: Changes in Industrial Structure

Source: Roberts et al (RDE 1998).

$\begin{array}{llll} & 1987 & 1993 & \text { "P } \\ \text { Mining } & 6.9 & 7.7 & 0 \\ \text { Metallurgy } & 2.8 & 1.8 & 1 \\ \text { Electro-Eng } & 13.3 & 7.9 & 1 \\ \text { Chemicals } & 3.6 & 2.8 & 0 \\ \text { Building mats } & 2.1 & 1.5 & 0 \\ \text { Wood and paper } & 2.1 & 2.0 & 0 \\ \text { Textiles } & 5.4 & 2.7 & 1 \\ \text { Food } & & & \\ \text { Other man } & 2.1 & 0.8 & 1 \\ \text { Construction } & 11.6 & 7 & 1 \\ \text { Agriculture } & 8.5 & 7.6 & 0 \\ \text { Transport/Comm } & 6.6 & 6.5 & 0 \\ \text { Prade } & 10.5 & 16.1 & 0 \\ & & & \\ \text { Other services } & 13.0 & 27.0 & 0\end{array}$

I have defined 'protected' sectors as those whose income shares declined by 30 per cent or more between 1987 and 1993: it can be seen that these comprised metallurgy, electro-engineering, textiles, other manufacturing, and construction (though the decline of the latter probably reflects the general recession in the Polish economy). By contrast, the only sectors whose income shares grew by more than $30 \%$ were trade and other services.

The sectors I have defined as 'protected' under Soviet socialism amounted to 35\% of Polish GDP in 1987, but only $20 \%$ by 1993 . Critically, these 'protected' sectors (henceforth aggregated as sector $P$ ) accounted 
in 1987 for $27 \%$ of the labour force, but $43 \%$ of capital payments - in other words they were considerably less labour-intensive than the 'unprotected' sectors (henceforth sector $N$ ).

A sectoral shift in demand towards labour-intensive sectors can potentially reverse the conclusions above about restructuring leading to real wage declines: if the decline is sufficiently concentrated in capitalintensive sectors, real wages can rise.

Whether this will happen depends partly upon the assumed nature of the protection of sector $P$ in the pre-transition period. Following in the spirit of the earlier sections, I assume that the protection was achieved effectively by an effective output tax on sector $N$ to pay for excessive output in sector $P$. This might happen in reality by forcing sector $N$ to purchase its inputs from sector $P$ at above World market prices.

In these circumstances, it is possible that the effects of closure of plant in sector $P$ could raise wages overall. The reason is that, in a clearing market model, labour is redeployed in sector $N$. While, in the absence of new firms entering, this will involve a fall in the real product wage in sector $N$, nevertheless real wages could conceivably rise if this is outweighed by the rise in the net real product price of good $N$ (which is no longer paying to subsidise sector $P$ ).

To investigate this possibility, a variant of the pre-transition Polish base data set was used, with a two-sector split (the breakdown of data based on Roberts et al, 1998). The initial composition of output before transition is assumed to be as follows: 
Table 6: Data for two-sector model based on Poland 1989 and 1987.

$\begin{array}{llll} & \text { Industry } P & \text { Industry } N & \text { Whole } \\ \text { Share of GDP } & 35 \% & 65 \% & \\ \text { Value added \$bn } & 24.67 & 45.82 & 70.49 \\ \text { o/w payment to labour \% } & 40.0 \% & 57.5 \% & 51.4 \% \\ \text { Payments to: } & & & \\ \text { Labour } & 9.87 & 26.35 & 36.22 \\ \text { Capital } & 14.80 & 19.47 & 34.28 \\ \text { o/w Fixed } & 7.40 & 9.74 & 17.14 \\ \quad \text { Variable } & 7.40 & 9.74 & 17.14 \\ \text { O/w interest } & 6.51 & 8.57 & 15.08 \\ \text { Depreciation } & 8.29 & 10.91 & 19.20 \\ \text { Capital Stock } & 118.43 & 155.79 & 274.22\end{array}$

It is assumed that sector $P$ received in the pre-transition period a subsidy to its output of $X_{0}$ per cent of its output value. This means that the cost to sector $N$ before transition is $X_{0} Y p_{0} / Y n_{0}$. This subsidy/tax is assumed to be removed during the transitional reforms, along with the cross-subsidies between firms within each industry.

Simulations were carried out of the reforms, assuming initially that no new firms open, and for three different levels of X0: zero, $10 \%$ of sector output and $20 \%$ of sector output. The results of the simulations are in Table 7 below: 
Table 7: Results of reform

$\begin{array}{llll} & \text { Pre-transition } & \text { Constant prob of death } \\ \text { Initial subsidy to P } & 0 & 0.1 & 0.2 \\ \text { Initial GDP } & 70.4 & 70.4 & 70.4 \\ \text { Final GDP } & 69.5 & 67.6 & 64.8 \\ \text { GDP index } & 98.7 & 95.9 & 97.0 \\ \text { Wage index } & 94.9 & 98.4 & 102.7 \\ \text { Prop of firms shut in P } & 36.6 \% & 49.2 \% & 68.5 \% \\ \text { Prop of firms shut in N } & 34.4 \% & 31.2 \% & 29.1 \% \\ \text { Initial NDP } & 50.5 & 50.5 & 50.5 \\ \text { Final NDP } & 54.0 & 52.9 & 51.1 \\ \text { NDP index } & 106.9 & 104.8 & 101.2 \\ \text { Long-term NNP } & 57.4 & 57.1 & 56.0 \\ \text { NNP index } & 113.7 & 113.0 & 110.9 \\ \text { Y(P) } & 22.9 & 15.0 & 7.5 \\ \text { Y(N) } & 46.6 & 52.7 & 57.3\end{array}$

It can be seen that, the larger the initial subsidies, the larger the shake-out of capiacity which would occur following transition, and hence the larger the fall in GDP if no new firms start up. The observed fall in the output share of sector $P$ (to $20 \%$ in 1993) is very similar to what would have been the result of the removal of a $10 \%$ output subsidy, combined with the shake-out of inefficient firms. This would be consistent, in a model with no new firms, with a fall in GDP of just over $4 \%$, and a slight fall of $1.6 \%$ in real wages (considerably less bad than indicated by the one-sector model). Had the initial subsidy to $P$ been slightly larger, say $20 \%$ of output, wages would actually have risen in our model, even without new firm startups.

The interaction of the two-sector model with new firm startups is an interesting one. Because net output prices in sector $N$ are now higher (no longer having to subsidise $P$ ), firm entry is more profitable at a given wage rate than in the one-sector model. This makes it more likely that output prices in the 
growing sector $N$ will be sufficiently high to overcome the entry $\operatorname{costs} S$ for new firms. If this is the case, then in the longer term new firm entry would be expected to bid wages up considerably.

This relationship can be seen in Table 8 below.

\title{
Table 8: Effects of varying setup cost on long run wage
}

\author{
$\mathrm{X} 0=$ initial subsidy to $\mathrm{P} \quad 0 \quad 0.1 \quad 0.2$
}

Setup Cost S

$\begin{array}{llll}0 & 1.10 & 1.20 & 1.29 \\ 0.25 & 1.06 & 1.15 & 1.25 \\ 0.5 & 1.02 & 1.11 & 1.20 \\ 0.75 & 0.99 & 1.07 & 1.17 \\ 1 & 0.95 & 1.04 & 1.13 \\ 1.25 & 0.93^{*} & 1.01 & 1.10 \\ 1.5 & 0.90^{*} & 0.98 & 1.07 \\ 1.75 & 0.88^{*} & 0.96^{*} & 1.04 \\ 2 & 0.85^{*} & 0.93^{*} & 1.02^{*} \\ \text { * } & \\ \text { wage with no new firms } & 0.95 & 0.98 & 1.03 \\ \text { * indicates cases where new firms } & \text { would not be set up, and the wage would be that in the final row. }\end{array}$

With no initial distortions between sectors $\left(X_{0}=0\right)$ the wage without any new firms would be $5 \%$ below pre-transition levels. With setup costs $S>1$ no new firms will enter, and this wage will prevail. By contrast, for $S<1$ wages will rise, to $10 \%$ above transition levels in the case where there is free entry.

When $X_{0}=10$ per cent (the level which seems most consistent with the observed changes in output), the wage without new firms is $2 \%$ below pre-transition levels. New firms will enter at setup costs of up to 1.5 , and for $S=1$ the long-run wage will be 4 per cent above pre-transition levels. With free firm entry the long-run wage could rise by up to 20 per cent.

For $X_{0}=20$ per cent the likelihood of new firms entering is even higher and the long-run gain to wages even greater. 


\subsection{Monopolistic effects}

In practice, an important feature of Soviet economies was the highly monopolistic industrial structure typically just one supplier in each industry within an individual Soviet bloc economy (Gros and Steinherr, 2004). Clearly, once prices were liberalised, this degree of monopoly power would give a huge potential for the new industrial barons to exploit for profit, at least in the short run.

In theory, there are three potential limits to a monopolist's profits: (i) the ability of consumers to switch to other goods or services, (ii) the cost of entry of new firms and (iii) the price charged by foreign competitors. In the case where overall elasticities of substitution between different goods are 1 or less (such as the Cobb-Douglas utility function we have assumed), the first limit does not apply. The monopolist will therefore charge a price equal to or just below the lesser of (ii) and (iii). For nontradable goods, or those with very high unit transport costs or remaining tariffs (after the post-Communist liberalisation), the appropriate limiting factor is the cost of entry for new firms. If we assume all new firms face the same expected setup cost, $S$, then we can estimate the price at which a new firm will enter as follows:

Alternatively, we can assume that foreign competition sets the limit to the monopolist's power. For non-exporting industries this simply means the monopolist will charge $P w_{g}+t_{g}+\tau_{g}$, where $P w$ is the world traded price of $g, t$ is the transport cost and $\tau$ is the tariff. If the industry is exporting, a key issue is whether arbitrage is possible between the domestic and foreign markets - if we assume this is the case then the maximum price the monopolist can charge (if he wishes to keep exporting) is $P w_{g}-t_{g}-\tau_{g}^{\prime}$, where $\tau_{g}^{\prime}$ is the foreign tariff on exports from the former Soviet bloc country. However, since I am assuming individual firms have upward-sloping supply functions, it is also possible that new entrants may come into the industry alongside the existing supplier, all selling at the world price (net of transport and tariff costs), so long as the country has a strong enough comparative advantage in the product to outweigh transport and tariff costs and the setup cost of the new firm. It is worth considering that this latter condition may be a major reason for the different behaviour post-transition of the EU accession states and the more remote former CIS economies.

To try and estimate how important this effect may be quantitatively, first consider the case of a closed 
economy where all goods are symmetrical. Fig 2 (Appendix) show the simulated relationship between setup cost and real wage in an economy based on Polish data and assuming an ongoing maintenance cost type depreciation. With perfect competition between old firms, real wages would fall to $94.7 \%$ of the pre-transition level (see Table 3 above). This corresponds to the real wage level at which firms will enter only if the setup cost falls below 0.963. It follows that, if the setup cost for a new firm is higher than this, and if all the old capacity is in the hands of a single producer, the monopolist can charge higher prices (so reducing wages further) without incurring the entry of new competitors. The higher the cost of new firm setup, the higher the prices the monopolist in each industry will charge, and the lower will be overall wages in real terms. A setup price of 1.5 would allow a monopolist to mark prices up by roughly 5.2 per cent over marginal cost, while a setup price of 2 would allow a markup of 11.4 per cent.

Figures 3a-b (Appendix) show the impact of a series of limit-pricing monopolies in all industries upon output and real wages. In Figure 3a, the demand curve for a representative industry is downward-sloping (elasticity of demand $=1$ in a Cobb-Douglas model). A perfectly competitive industry would produce output $Q^{*}$. However, if the monopolist charges above $P=P^{\prime}$, which corresponds to demand level $Q=Q^{\prime}$, new competitors can enter, so this sets the limit to the monopolist's price. ${ }^{8}$ This produces a kink in the demand curve, and a discontinuity in the marginal revenue curve, so that the monopolist always produces $Q=Q^{\prime}$ in a partial equilibrium model.

In Figure 3b, all firms in the industry are monopolistic and reduce output and labour demand. Wages are driven down. This shifts the marginal cost curve downwards by a constant factor $w^{\prime}$ (the new wage rate, since I assume initial wages were 1$)$, to the point where the kink (which occurs at $\left.P^{\prime}=M C\left(Q^{\prime}\right)(1+\mu(S))\right)$ will eventually occur at the initial demand level $Q^{\prime}$. This leads to total output being unchanged, but wages being reduced across the economy to allow for a monopolistic margin $\mu$.

In the next case I consider, not all industries are identical. Rather, there is an export industry whose price rises after the economy opens up. This is sufficient to outweigh the setup cost for new firms, $S$, so

\footnotetext{
${ }^{8}$ We can say $P^{\prime}=M C\left(Q^{\prime}\right)(1+\mu(S))$, where $\mu(S)$ is the monopolist's margin, which is an increasing function of new firms' setup cost, $S$.
} 
that at a wage of $w "$ the demand curve for labour is flat. If labour is perfectly mobile between sectors, this sets a limit of $w$ " below which the demand curve cannot fall (so that the marginal cost curve cannot be shifted down by a factor of more than $\left.w^{\prime \prime}\right)$. Consequently, the monopoly in the non-export industry does cause a fall in output in that industry, though not by as great an amount as in the first partial equilibrium case. This is shown in Figure 3c.

\subsubsection{Interaction with Factor Immobility.}

There are general equilibrium models of the effects of trade price changes in economies with factor mobility costs. ${ }^{9}$ Clarete et al (1991) and Edwards and Whalley (2003) examine the effects of partial factor mobility, where a factor cannot move between sectors unless the wage differential exceeds a certain proportion of the wage, say $\lambda$.

In our model, if there are no intersectoral mobility costs, but there is an export sector whose price increase following liberalisation is enough to outweigh the setup cost for new firms, $S$, then the wage in the expanding export sector $w$ " will set the wage across all sectors. By contrast, if there are mobility costs on labour, then, even if long-term there are profitable opportunities to set up export firms, they may have trouble obtaining labour in the short run. In the Clarete et al model, wages in declining sectors can fall to up to fraction $\lambda$ below those in expanding sectors. In countries with high mobility costs, this may imply wages in import-competing or nontradable sectors can fall well below those in any expanding exportable goods sector, which in turn makes it possible for monopolistic firms in the former sectors to charge quite considerable profit margins.

\subsection{The case of Russia}

Russia's economy has a number of special features. While a slow reformer compared to the EU accession states of Central and Eastern Europe and the Baltics, it has nevertheless privatised large sections of its economy and liberalised prices (unlike many of the other CIS states). While its output performance may not have been as bad as many other CIS states, it has seen a huge increase in inequality, perhaps reflecting

\footnotetext{
${ }^{9}$ See e.g. Mayer, 1974, Mussa, 1974, Neary 1978 for theoretical analysis.
} 
its intermediate reforming status.

Several factors may have led Russia to have much worse results in terms of wage levels and inequality compared to the EU accession states. Firstly, its size and relative remoteness from the rest of the World mean it is generally more closed than the economies closer to Western Europe.

Secondly, Russia's export sector is dominated by oil and gas. Fuels accounted for 58.8 per cent of the total value of the Russian Federation's exports in the period Jan-July 2003. ${ }^{10}$ Oil production is generally a capital-intensive industry, and its expansion in any case depends upon discovery and permission to exploit new reserves, which may have long lead-times.

Thirdly, Russia's spread-out geography means that there are many isolated towns, often dominated by a single firm or industry. This should potentially imply high labour mobility costs. Despite this, actual measured job mobility was somewhat higher in Russia than in Hungary or Poland in 1998 (EBRD, 2000 Table 5.4), although Russians tend to move to public-sector jobs, rather than to private-sector jobs as in Hungary or Poland. A truer reflection may be the higher wage differentials in Russia (financial services compared to agriculture: a ratio of 3.8:1 in Russia compared to 2.2:1 in the Czech Republic or 2.4:1 in Poland in 1996).

The EBRD's Transition Report 2000 shows quite clearly the difference in business climate between Russia/Belarus/Ukraine ('Central CIS') compared to the EU accession states. The degree of pressure, both from domestic competition and from foreign competition, is much less in the Central CIS states: this may be a contributing factor to the poor performance of wages in these economies.

\footnotetext{
${ }^{10}$ Source: BDO Unicon-Ruf Centre for Macroeconomic Researches. http://www.bdo.ru/en/press/market/139/
} 
Table 9: Importance of pressure from domestic and foreign competitors ${ }^{11}$

$\begin{array}{llllll} & & \text { Privatised } & \text { State } & \text { New Entrants } & \text { Total } \\ \text { Domestic comp } & \text { Cent Eur \& Baltic } & 29 & 20 & 32 & 30 \\ & \text { SE Europe } & 32 & 17 & 33 & 29 \\ & \text { Central CIS } & 13 & 9 & 16 & 15 \\ & \text { CIS Periphery } & 17 & 6 & 17 & 15 \\ & \text { Total } & 22 & 14 & 25 & 22 \\ \text { Foreign comp } & \text { Cent Eur \& Baltic } & 31 & 24 & 16 & 22 \\ & \text { SE Europe } & 32 & 20 & 20 & 23 \\ & \text { Central CIS } & 9 & 2 & 8 & 9 \\ & \text { CIS Periphery } & 11 & 6 & 8 & 9\end{array}$

On the barriers to new firm entry, it is worth noting that the EBRD (2000 table 8.2) compared barriers to entry and expansion for recent entrants in the four regions: the Central CIS performed worse than Central Europe and the Baltic States for recent entrants on - taxes and regulations, inflation, financing and infrastructure, but better on corruption and anti-competitive practices. The Central CIS had considerably improved its relative position compared to the early transition. South-Eastern Europe and the CIS Periphery performed badly on all counts, while the main barriers to expansion of SOEs were lower in all categories for the Central European/Baltic States compared to the other groups.

\section{Capital Controls and Transition}

In general, neoclassical theory would suggest that free international movement of capital would maximise welfare. However, in practice this conclusion is subject to many qualifications - such as the interaction with taxes/subsidies, the effects of capital market uncertainties, panics etc, the avoidance of money-laundering and the like.

\footnotetext{
${ }^{11}$ Source, EBRD (2000) Table 7.2
} 
It is worth briefly discussing here whether the removal of capital controls from countries engaging in substantial restructuring can result in adverse effects from the point-of-view of wage-earners. The argument is that, if restructuring creates supranormal profits for the inheritors of the former state industries, but at the same time opportunities for the profitable development of new firms are limited, then capital is likely to be reinvested abroad. This would be expected to raise the return to the capital-owners (if investment abroad is more profitable), but its effects on labour demand, and hence wages, will depend upon whether capital and labour are substitutes or complements. There are strong reasons to believe the latter may well be the case, especially in the short- to medium-run in an economy being restructured, since a higher cost of capital will imply a greater rate of plant closures. In the longer term, much depends on the technical rates of substitution between capital and labour in existing and in new firms.

The table below suggests that this is almost uniquely a Russian problem. The CEEC, Baltic and Balkan economies have all seen strong net capital inflows, in part reflecting their potential as exporters to Western Europe. By contrast, Russia has seen large-scale privatisation and considerable restructuring of industry, yet it is relatively far removed from Western markets and the economic climate has not favoured the growth of new export industries, except in oil and gas. Consequently, Russia has consistently run large trade surpluses during the period 1994-2003, reflecting ongoing capital outflows. 
Table 10 : Average Current Account Balances, 1994-2003. ${ }^{12}$

Average current account balance

$\begin{array}{ll}\text { Croatia } & -5.2 \\ \text { Czech Rep } & -4.5 \\ \text { Estonia } & -8.4 \\ \text { Hungary } & -4.6 \\ \text { Latvia } & -6.0 \\ \text { Lithuania } & -7.6 \\ \text { Poland } & -2.7 \\ \text { Slovak Rep } & -5.6 \\ \text { Slovenia } & 0 \\ \text { Albania } & -8.8 \\ \text { Bulgaria } & -2.3 \\ \text { Romania } & -4.8 \\ \text { Russia } & 6.8 \\ \text { Ukraine } & 1.0 \\ \text { Belarus } & -4.2\end{array}$

It follows that, while the CEECs, Baltics and Balkan States were mostly highly dependent upon foreign capital inflows to maintain investment in new industries, the capital outflows from Russia amounted to a high proportion of Russian investment.

There is, of course, no guarantee that, even had Russia imposed capital controls, the flight could adequately have been stemmed, or that even if it had, the extra capital within Russia would have been used to increase investment and industrial capacity. Interest rates might have been lower ${ }^{13}$ - but it is quite

\footnotetext{
${ }^{12}$ Source, EBRD Transition Report, 2003, Table A.3.7
}

${ }^{13}$ The mechanism by which interest rates in the short run would be lower in a country running down its capital stock if it prevents capital flight is that the capital shake-out yields a one-off windfall income in the short term. Given the desire of the inheritors of this windfall to smooth consumption (the marginal utility of consumption being assumed to decline), there would be a desire to delay consumption of this windfall, which would offset the underlying time preference, and lead to lower interest 
conceivable that even substantial interest rate reductions might have been insufficient to produce much investor response in the presence of poor export prospects, inflation, corruption and insecure property rights/political uncertainty at home.

\section{Conclusions}

In this paper, I have investigated the implications of a number of models of post-communist restructuring. In particular, I have applied a batting order approach, based upon the assumption that, under the Soviet system, inefficient capacity was maintained rather than shut, and that this was financed from the profits of the more successful enterprises. The result was that capital investment was diverted towards inefficient uses, so that even if there were a high rate of investment relative to GDP, this would simply lead to an expansion of wasteful capacity, to the point where the depreciation costs of this capacity used up all the new investment. Unlike a simple one-sector neoclassical model, this model explains how a Soviet model could have high rates of investment and wasted capital, and yet at the same time have a low capital stock per head by Western standards.

A shake-out of inefficient capacity in this type of model would lead to a sharp fall in output, as measured by GDP. In a sense, this fall is misleading, since what is being removed is in fact more than outweighed by the saving in wasteful replacement investment. However, this saving may not benefit everybody: if existing capacity has been privatised at a low realised price, then the gains accrue overwhelmingly to the new industrial barons, while wages fall more or less in line with GDP.

With a mixture of numerical general equilibrium simulations and discussion, I then investigate a number of variations on this basic model. If the Soviet system resulted in over-investment (modelled as below World real interest rates) then reform would result in larger initial falls in GDP and wages, and the above conclusions would apply to an even greater extent. By contrast, if capital-intensive sectors had been subsidised by the Soviet system, then the effects on wages would be substantially mitigated as these sectors shrink, while labour-intensive services grow, in the post-transition period. This effect may be a reason for

rates during the transition period. The precise effects of this would require a dynamic model to investigate numerically. 
wages holding up better in some countries (e.g. Poland) than a simple batting-order model might indicate.

The setup of new firms turns out to be highly significant in two respects in this model. First, if setup costs are low, then new firms may enter at only slightly below (or even, in some cases, above) pre-transition wage rates, setting a floor to wages. This is more likely to be the case the better established is the legal and property framework, and also the greater are the opportunities for development of new export industries (hence the prospects of this happening are much greater in EU applicant countries). Secondly, new firms set a limit to monopolistic pricing - an important factor given the highly concentrated pre-transition industrial structure of most of these economies. In the absence of new firm entry, import competition is likely to be the main limiting factor to monopoly pricing.

This analysis suggests in part why the experience of the CEEC economies has been so different to that of the former Soviet Union. The former countries are nearer the West (lower trade costs) and some have now joined the EU (hence they have inherited from abroad a more business-friendly legal framework). Some also already had private sector involvement before the Soviet breakup, which may have made the institutions and human capital inheritance more favourable to new business startups. Secondly, the CEEC countries face much keener competition from EU firms. The results are that they have to a large extent escaped the fate of the former Soviet Union, whose old monopolistic industries have retrenched yet yielded high profits in many cases to the new generation of oligarchs, while the slower reform climate and lack of export opportunities (other than in oil) have led to a lack of investment opportunities at home and a capital flight. A brief discussion suggests that, while free international capital movement has probably helped wage-earners in the CEECs (which have benefited from sizeable inward investment flows, driving up wages) the former Soviet economies might have been better initially to restrict capital outflows. 


\section{References}

[1] Alesina, A. and D.Rodrik (1994): 'Distributive Politics and Economic Growth', Quarterly Journal of Economics v109, n2 (May 1994): 465-90

[2] Blanchard, O. (1997): 'The Economics of Post-Communist Transition,' Clarendon Lectures, Oxford.

[3] Castanheira, M. and G.Roland (2000): 'The Optimal Speed of Transition: a General Equilibrium Analysis.' International Economic Review v 41 no 1, (Feb 2000) pp 219-39.

[4] Gros, D. and E.Jones (1991): 'Price reform and energy markets in the Soviet Union and central Europe', CEPS Working Document NO 57, Centre for European Policy Studies, Brussels.

[5] Gros, D. and A. Steinherr (2004): 'Planting the Seeds.' London and New York, Longman.

[6] Milanovic, B. (1999): 'Explaining the Increase in Inequality during Transition ', Economics of Transition v7, n2 (1999): 299-341

[7] Rauch, J.E. (1999): 'Networks versus Markets in International Trade.' Journal of International Economics Vol 48 Issue 1 pp 7-35.

[8] Roberts, Barbara M, J.I.Round and Z.Zolkiewski (1998): 'Structural Features of Economic Reform in Poland.' Review of Development Economics, v2 no 2 (June 1998) pp 211-30. 


\section{APPENDIX 1: Figures}

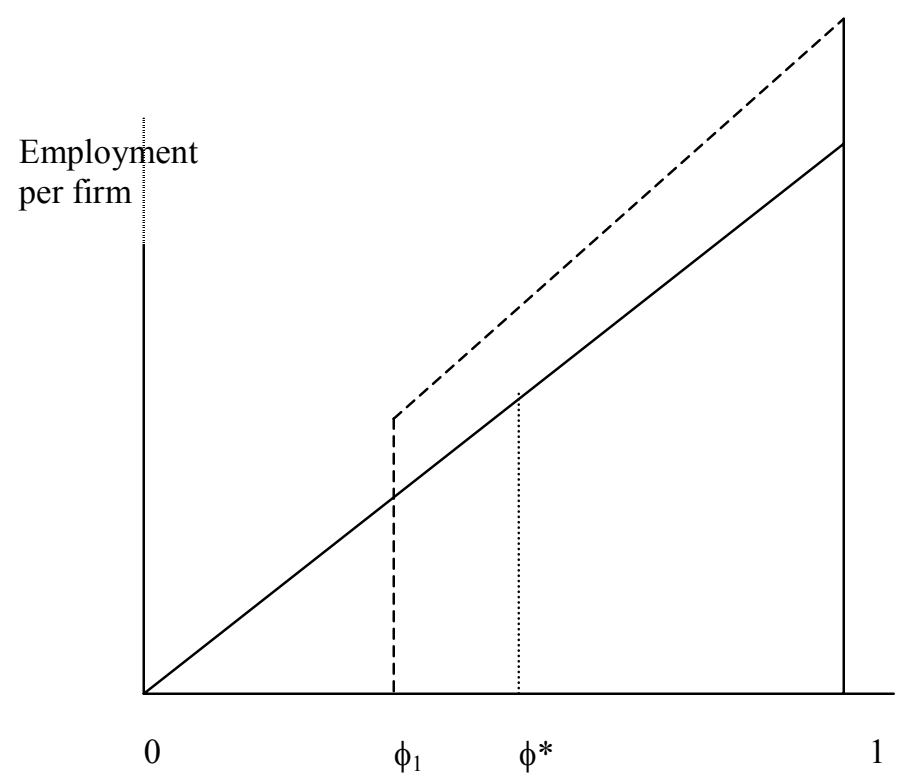

Firm efficiency, $\phi \mathrm{f}$

Figure 1: Employment per firm and firm efficiency before and after a transitional reform. 


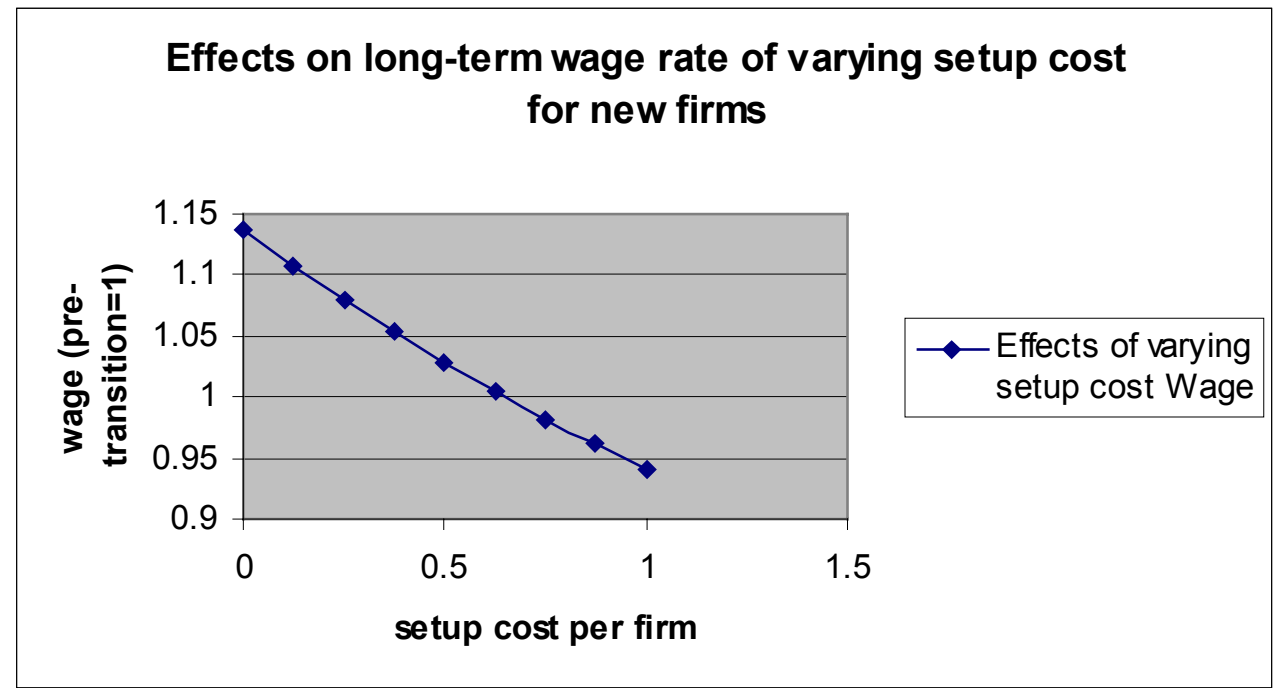

Figure 2: Effects on long-term wage rate of varying setup cost for new firms. 
Figures 3a-b: Monopolistic markups with limit pricing.

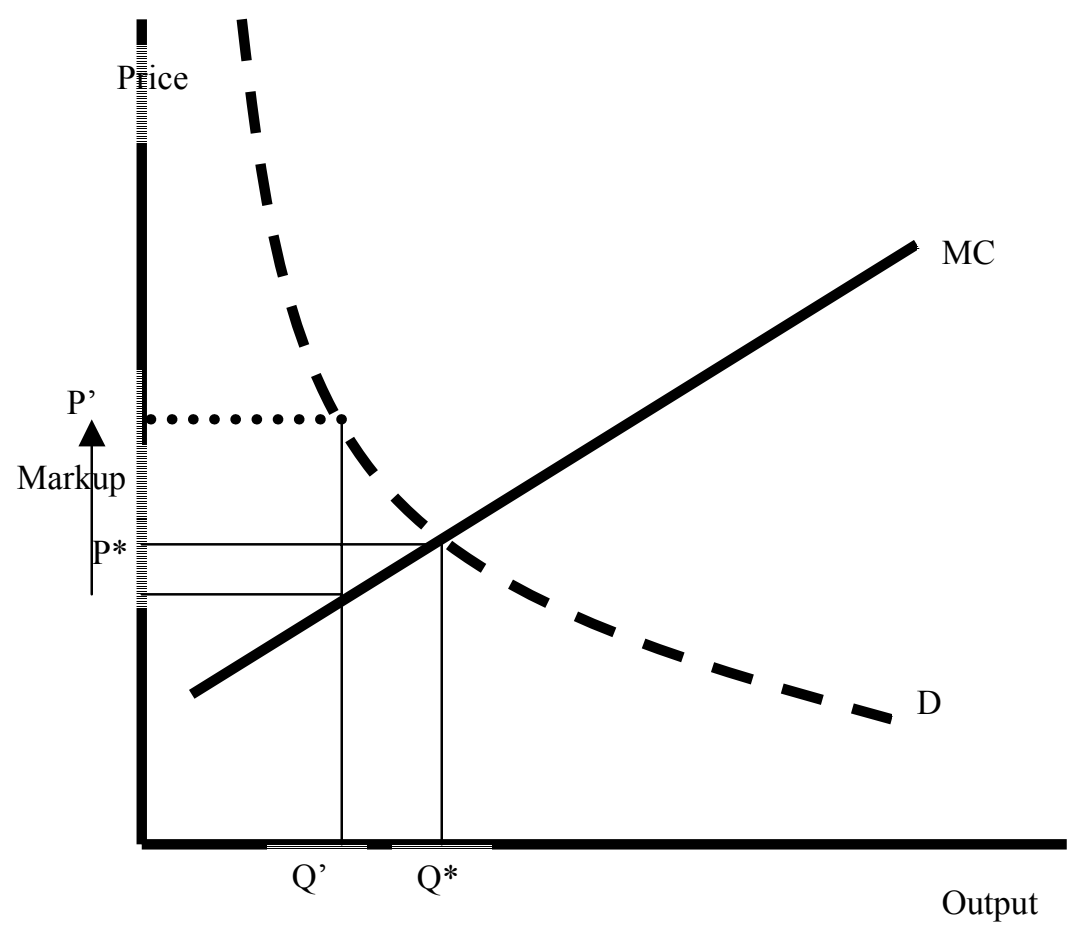

Fig3a: Effect with initial wages

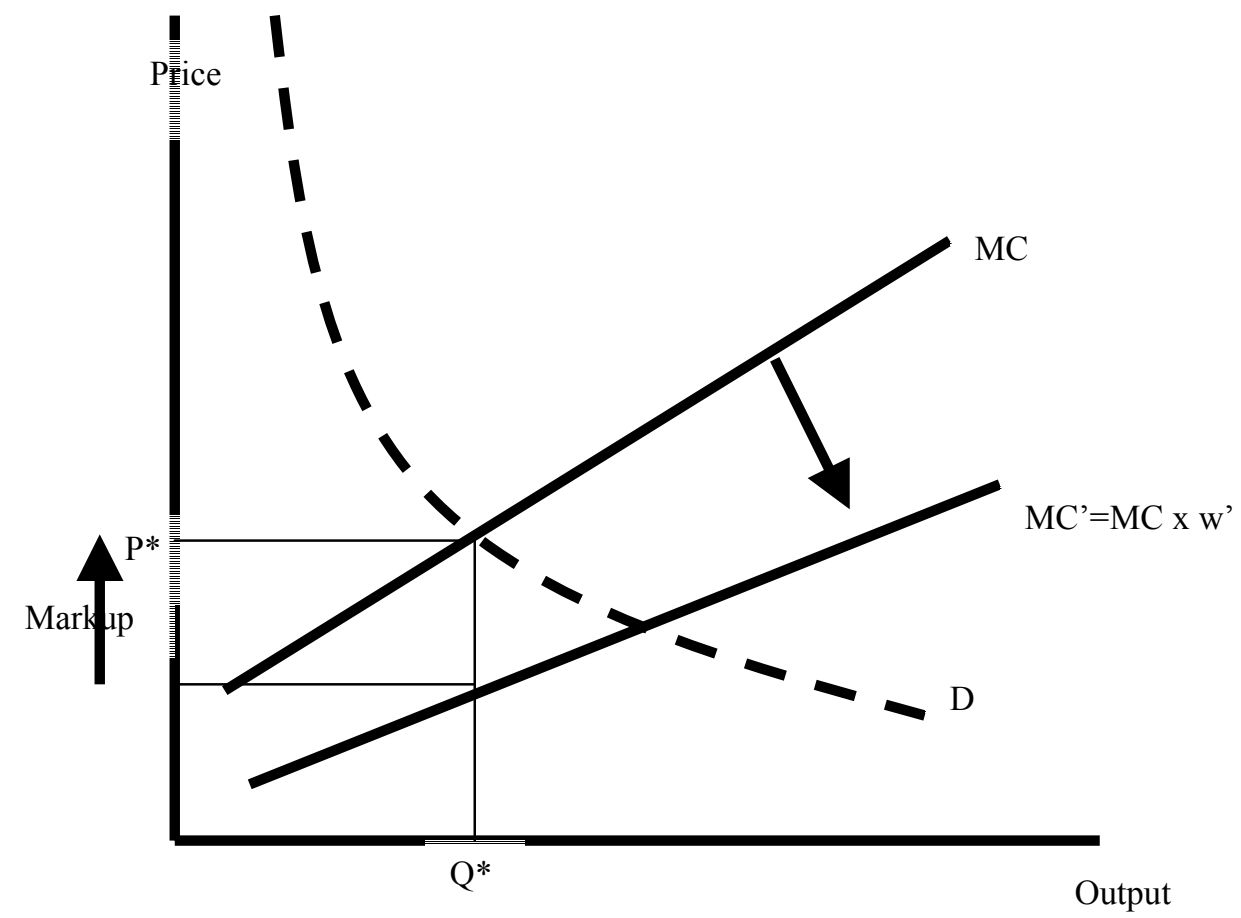

Fig 3b: Downward shift in marginal cost and wages. 


\section{APPENDIX II: The basic model used}

We assume there are initially $F_{0}$ firms in the pre-transition economy, employing one unit of capital each.

Output by firm $f$ is a function of efficiency, $\phi_{f}$, and labour employed $L_{f}$.

$$
Y_{f}=A \phi_{f}^{1-\alpha} L_{f}^{\alpha} .
$$

If the wage is $\mathrm{w}$, and we normalise the output price at unity, then we can derive pre-transition output, employment and operating profits (assuming each firm maximises profits).

$$
\begin{aligned}
L_{f} & =(w / \alpha A)^{1 / \alpha-1} \phi_{f}, \\
Y_{f} & =A(w / \alpha A)^{\alpha / \alpha-1} \phi_{f}, \\
\pi f & =(w / \alpha A)^{\alpha / \alpha-1} A(1-\alpha) \phi_{f} .
\end{aligned}
$$

Assuming pre-transition efficiency $\phi_{f}$ is uniformly distributed between 0 and 1 , average pre-transition firm efficiency equals $1 / 2$, which allows us to calculate total pre-transition employment and profits

$$
\begin{aligned}
& \overline{Y_{0}}=\left(F_{0} / 2\right) A(w / \alpha A)^{\alpha / \alpha-1}, \\
& \bar{L}_{0}=\left(F_{0} / 2\right)(w / \alpha A)^{1 / \alpha-1},
\end{aligned}
$$

where $F_{0}$ is the pre-transition number of firms.

It is possible to calibrate this model from the size of GDP and the share of labour in GDP, assuming the output price is unity and firms employ one unit of capital each. We can easily show that $\alpha$ equals labour's share in GDP (in this regard our model is very similar to a Cobb-Douglas production function). Since we are assuming that all operating profits (capital's share of GDP) is used up in interest costs and depreciation, it is easy to find the amount of capital employed (and hence the number of firms) by dividing capital's share of GDP by interest plus depreciation. Finally we can calculate $\bar{L}_{0}$ by dividing labour's income by the wage rate (normalised initially to 1 ) and then invert equation (8) to obtain the scale parameter $A$.

Prior to transition, assume each firm $f$ receives a net subsidy $Z_{f}$. This is required to cover the interest 
and depreciation costs of the firm $(=r+\delta)$, if pre-transition profits $\pi_{f}$ are insufficient. Since $\pi_{f}$ follows a uniform, linear distribution, it follows that $Z_{f}$ is also uniformly linearly distributed. We now assume that the profits for the industrial sector as a whole (pre-transition) exactly cover interest and depreciation. Consequently, profits for the average firm $\left(\phi_{f}=1 / 2\right)$ exactly cover interest plus depreciation. This is the breakeven firm quality before transition, $\phi_{0}^{\prime \prime}$.

Total subsidies paid to those receiving subsidy before transition can be shown to equal

$$
\bar{Z}_{0}=\left(\bar{F}_{0} / 2\right) \phi_{0}^{\prime \prime}(r+\delta)
$$

After transition, we denote the proportion of firms which eventually closes by $\phi_{d 1}$ or $\phi_{d 2}$, depending on which depreciation model is applied. Assume first that it is too costly to start up new enterprises, so that the number of firms falls following the transition restructuring. Using the first depreciation model, all firms will eventually close which do not make a profit greater than $(r+\delta)$ at the new equilibrium wage rate $w_{d 1}$. We note that

$$
\phi_{f} w_{0}^{\alpha /-1} A^{1 / 1-\alpha} /\left(\alpha^{\alpha / 1-\alpha}-\alpha^{1 / 1-\alpha}\right)=r+\delta-Z_{f}
$$

If we assume in the pre-transition economy that no firms shut, then for the most unsuccessful firm $Z_{0}^{\prime}=r+\delta$. We can rewrite these equations as:

$$
\phi_{d 1}=(1 / 2) w_{d 1}^{\alpha / 1-\alpha}
$$

This will equal the proportion of firms which close, which is an increasing function of the wage rate.

If the labour market clears, and there is a fixed labour supply, then we can derive the total demand for labour by integrating (4).

$$
\bar{L}=\left(F_{0} / 2\right)\left(w_{d 1} / \alpha A\right)^{1 / \alpha-1}\left(1-\phi_{d 1}^{2}\right)
$$


which implies that

$$
w_{d 1} / w_{0}=\left(1-\phi_{d 1}^{2}\right) .
$$

For $0<\phi_{d 1}<1$ and $0<\alpha<1$ this yields the important result that real wages fall following the transition.

Since the labour share in total output in this model is always equal to $\alpha$, it follows that the fall in GDP will be the same as the fall in wages.

However, gross domestic product does not equal real consumption: for one thing, the interest and depreciation costs of investment need to be netted off. Real consumption should rise following the restructuring process, since for each firm which closes, output less wages falls short of the replacement and interest cost of the capital saved. It follows that the benefits of the restructuring process are entirely in the form of higher net profits (after subtracting depreciation and interest).

\subsection{Depreciation as annual ongoing cost}

Now consider the alternative depreciation model, where depreciation is of the form of an ongoing maintenance cost of $\delta$ per unit capital per annum.

In this case, the only expenditure a firm can avoid by withdrawing from production is the annual maintenance $\operatorname{cost} \delta$. Hence we can calculate $\phi_{d 2}$, the proportion of firms which will shut

$$
\phi_{d 2}=(\delta / 2(r+\delta)) w_{d 1}^{\alpha / 1-\alpha} .
$$

This is a smaller proportion of firms shutting than under the previous form of depreciation. Consequently the average efficiency gain of the remaining firms (the batting order effect) is less.

For wages, we can show that

$$
w_{d 2} / w_{0}=\left(1-\phi_{d 2}^{2}\right)^{1-\alpha} .
$$

Since the $\phi_{d 2}>\phi_{d 1}$, this implies a smaller fall in real wages than in the first depreciation case. Again, GDP falls by the same proportion as wages. 


\subsection{Entry of new firms}

Assume a new business $g$ starts up again with a random $\phi_{g}$, chosen from a uniform distribution between 0 and 1. The firm has a one-off setup cost of $S$, and we assume that all businesses are price-takers. In this case, the firm will enter provided its expected present value of entering is greater or equal to zero.

The entry process can be split into two stages. The firm enters the market, and then finds out what its underlying efficiency, $\phi_{g}$ is. In our model, the firm will always make positive operating profits, but these may well fall short of interest and depreciation costs.With probability $\phi_{d 2}$ as given in equation (14) the firm will immediately withdraw from production, as it turns out to be unsuccessful. The ongoing loss will just be the interest cost $r$ per annum. By contrast, with probability $\left(1-\phi_{d 2}\right)$ it will continue to produce indefinitely, with the operating profits sufficiently high to cover the cost of ongoing maintenance. Expected annual profits in this case will equal

$$
\pi_{d 2}^{e}=(r+\delta)\left(\left(1-\phi_{d 2}^{2}\right) w_{d 2}^{\alpha / \alpha-1}-1\right)+\phi_{d 2}^{2} \delta
$$

New firms will enter the market if expected annual profits exceed the annual interest on the setup costs, i.e. if

$$
(r+\delta)\left(\left(1-\phi_{d 2}^{2}\right) w_{d 2}^{\alpha / \alpha-1}-1\right)+\phi_{d 2}^{2} \delta>S
$$

This will happen if

$$
S<(\delta / r)\left(1-w_{d 2}^{1 / 1-\alpha}\right)^{1 / 2}-((r+\delta) / r)\left(1-w_{d 2}\right)
$$

Alternatively, if we are looking at whether enough new firms can enter to allow real wages to rise above $w_{0}(=1)$, then we can substitute $w_{d 2}=1$ into equation (18). This can be shown to correspond to

$$
S<\delta^{2} / 4 r(r+\delta)
$$

